\title{
Evaluation of the Effects of Bismuth Subgallate on Wound Healing in Rats. Histological Findings
}

\author{
Rafaela Mabile Ferreira dos Santos ${ }^{1}$ Claudia Paraguaçu Pupo Sampaio ${ }^{1}$ Daniela Pache de Moraes ${ }^{1}$ \\ Rubianne Ligório de Lima ${ }^{1}$ \\ ${ }^{1}$ School of Medicine, Pontifícia Universidade Católica do Paraná, \\ Curitiba, Paraná, Brazil \\ Int Arch Otorhinolaryngol 2016;20:377-381. \\ Address for correspondence Rafaela Mabile Ferreira dos Santos, MS, \\ Pontifícia Universidade Católica do Paraná - School of Medicine, \\ Rua Imaculada conceição n.1155 Curitiba Paraná 80215901, Brazil \\ (e-mail: rafa_mabile@yahoo.com.br; danielapachedemoraes@hotmail.com).
}

\begin{abstract}
Introduction Bismuth subgallate (BS) is a yellow and odorless powder that has hemostatic astringent properties. Some otorhinolaryngologists and dentists currently use this substance to enhance wound healing.

Objective The objective of this study is to evaluate the effects of bismuth subgallate on wound healing, through the analysis of inflammatory process, collagen production, and angiogenesis.

Method A standard wound was made on the back of 60 male Wistar rats, using a biopsy punch. We created two groups: the experimental group, which underwent daily application of $0.5 \mathrm{mg} B S$ over the entire wound, and the control group, which underwent daily application of sodium chloride $0.9 \%$. We performed a qualitative evaluation of the tissue on the third, seventh, and fourteenth day. We assessed inflammatory markers using Hematoxylin and Eosin (HE) stain, used Picrosirius stain for collagen analysis, and immunohistochemistry was used for angiogenesis analysis through evaluation of smooth muscle proliferation.

Results Statistically, we found no significant differences between groups regarding inflammatory response on the third $(p=1)$, seventh $(p=0.474)$, and fourteenth day $(p=0.303)$. Also, collagen type I and III production showed no statistical differences between groups on the third $(p=0.436)$, seventh $(p=0.853)$, and fourteenth day $(p=0.436)$ of analysis. Immunohistochemistry did not present differences on angio-

Keywords

- bismuth subgallate

- angiogenesis

- wound healing genesis between experimental and control group on the third $(p=0.280)$, seventh $(p=0.971)$, and fourteenth day $(p=0.218)$.

Conclusion BS does not promote significant changes in inflammatory response, collagen, and angiogenesis. Thus, it does not influence healing on skin wounds on rats.
\end{abstract}

\section{Introduction}

Intra and postoperative hemorrhage are relevant issues for surgeons due to its association with high mortality. Despite the existence of hemostatic agents for years, this subject is not fully elucidated. There are two main types of agents that prevent hemorrhage: hemostatic agents and tissue adhesives. Each of these substances differ in their mechanism of action, cost, and application method. ${ }^{1}$

received

July 17, 2015

accepted

March 17, 2016

published online

May 4, 2016
The mechanism of action of hemostatic agents may be mechanical or through action over the coagulation cascade. On the other hand, tissue adhesives are substances that close wound edges. Collagen is considered a topic hemostatic agent, and it is biomaterial derived from organic tissues. It has considerable tension force as a characteristic. Furthermore, it has high affinity for water, low antigenicity, and is absorbed by the body promoting platelet activation. Collagen

Copyright $\odot 2016$ by Thieme Publicações License terms Ltda, Rio de Janeiro, Brazil

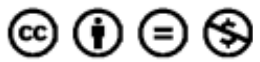


may be applied on the bleeding site. Although bovine collagen may lead to allergic reactions or immune reactions, the incidence of such events in clinical practice is low. ${ }^{1}$

Cellulose-based products contain oxidized regenerated cellulose. They trigger coagulation through contact activation; however, the exact mechanism has not been elucidated. Cellulose-based products may be cut in different sizes to adapt to the exact size of the wound. These products are easy to use and do not adhere to surgical instruments. Nonetheless, the body may not absorb oxidized cellulose as well as other products. Differences in biodegradability will depend on the quantity used and place of implantation. This way, a minimal quantity should be used to obtain hemostasis. ${ }^{1}$

Bismuth subgallate (BS) is a yellow and odorless powder. The compound is stable in air, but suffers discoloration under the influence of sunlight. ${ }^{2}$ Its homeostatic and astringent properties have led to increasing use by dentists and ear, nose, and throat (ENT) surgeons. Due to these characteristics, its use is diverse and comprises dental surgery, peptic ulcer disease treatment, wound treatment, diarrhea management (0.1-2 g orally), odor control in colostomies (0.1-2 g orally), epistaxis management, as well as, empirical use in adenotonsilectomies. ${ }^{2-4}$ The recommended dose via rectal route is $0.1-2 \mathrm{~g}$ and $20 \%$ may be used for topic application.

This study addresses BS regarding the fact that published trials addressing the effects of BS on wound healing are limited. Furthermore, there are diverging reports on its use. Whereas some departments of otorhinolaryngology do not encourage the utilization of BS under the premise that its post-operative effect is not significantly beneficial, other departments claim great pro-homeostatic results associated with its topical application. The aim of this study is to evaluate the influence of BS on wound healing phases. Given that BS has low cost and is easily applicable, it could benefit wound healing. The histological analysis of inflammatory process, collagen production, and angiogenesis may demonstrate the benefits of its use, thus, optimizing the wound healing process. Furthermore, BS trials have not specifically explored its wound healing effects. Generally, they have addressed its effects on post-operative immediate bleeding.

The classical wound healing phases are: hemostasis, inflammation, proliferation (epithelialization, collagen deposition, angiogenesis, granulation tissue formation, and wound contraction) and remodeling. ${ }^{5-7}$ The earliest stage is hemostasis and consists of an immediate response to injury, comprising the formation of a clot and a transitional wound matrix, through which cells migrate during repair. ${ }^{8}$ Inflammation manifestations are due to augmented blood flow and vascular permeability. They consist of: pain, heat, redness, swelling, and loss of function.

Substantial effort has been given to elucidating the physical relationships driving wound healing. The utilization of resources to stimulate this process should be applied to acute wounds, thus preventing chronification and its adverse effects. Wounds that do not heal within eight weeks are considered chronic. ${ }^{9}$ Considering this, the aim of this study is to evaluate the influence that BS may have over any of the wound healing phases. Our research will employ histological analysis. Given the fact that BS has low cost and is easily used, its use could benefit wound healing.

\section{Method}

This study took place at the Surgical Technique Experimental Laboratory. The sample comprised 60 male Wistar rats $(n=60)$ (Rattus norvegicus albinus, Rodentia mammalia), 110 days old and weighing 250-300 g. Ethical approval was granted by Animals Ethics Committee, under protocol number 720 . The animals from this study also participated in the concomitant project: "Evaluation of the effects of bismuth subgallate on myofibroblasts proliferation: an experimental study on rats."

We determined the sample size by literature analysis. We randomly created two groups of 30 animals. We then divided the animals into subgroups of 10 . Therefore, the control and experimental group comprised 3 subgroups of 10 rats. Animals in both groups underwent anesthesia with ketamine (50 mg) and xylazine $2 \%(20 \mathrm{mg})$, at a concentration of $0.1 \mathrm{ml} / 100 \mathrm{~g}$ of animal body weight. Intramuscular application was done on the posterior portion of thigh. Animals were placed in ventral decubitus and had their superior and inferior limbs adhered to a wooden support. We performed a trichotomy of $24 \mathrm{~cm}^{2}(6 \mathrm{~cm} \times 4 \mathrm{~cm})$ on the ratś backs. This area was demarcated by means of an imaginary line traced between inferior limbs that extended progressively in caudal direction. Subsequently, we performed skin antisepsis with polyvinylpyrrolidone-iodine (PVPI) and delimited the operative area with a fenestrated sterile field. Wounds were standardized with biopsy punches. We made a circular excision and deepened it down until dorsal muscle fascia. Intramuscular Diclofenac Potassium $10 \mathrm{mg} / \mathrm{Kg}$ was administered, as a post-operative analgesic and anti-inflammatory.

The experimental group underwent daily applications of $0.5 \mathrm{mg}$ BS over the entire wound. The control group underwent daily application of sodium chloride $0.9 \%$, as recommended by literature. ${ }^{10}$ We created subgroups to analyze tissue at different times. To do so, animals were re-operated for wound excision, on the third, seventh, and fourteenth day. The animals underwent anesthesia (as previously described), and the wound was excised with gross margin of $1 \mathrm{~cm}$ of normal tissue. Incision was deepened until dorsal muscle fascia. We administered intraperitoneal thiopental (120 mg/ $\mathrm{kg}$ ) to each subgroup after excision of wound for the purpose of euthanasia. No animals were lost throughout this study.

We placed excision specimens on a paper card and identified them. Subsequently, we immersed tissues in formaldehyde $10 \%$ for 24 hours, and then processed into paraffin. Blocks were sectioned and stained with Hematoxylin and Eosin (HE). Optical microscopy analysis of one section of each rat was then conducted with $40 \mathrm{x}$ image magnification. We did cell counts on slides stained with HE to analyze inflammatory process stage. We performed the polymorphonuclear and mononuclear cell count on all slides, then placed the total cells on a table for classification of wounds into acute, subacute, or chronic. ${ }^{11}$ (- Table 1) 
Table 1 Cell count of inflammatory process and characterization of inflammatory process stage according to the final score of each group

\begin{tabular}{|l|l|l|l|l|}
\hline Cell Count & Polymorphonuclear & Monomorphonuclear & IPS & Classification \\
\hline$<50$ & -1 & 1 & Acute & -9 to -3 \\
\hline $50-100$ & -2 & 2 & Subacute & -2.9 to 3 \\
\hline$>100$ & -3 & 3 & Chronic & 3 to 9 \\
\hline
\end{tabular}

Abbreviation: IPS, inflammatory process stage.

We used Picrosirius red stain to analyze collagen by evaluating differences in intensity of birefringence. We examined sections using a Polarizing microscope. We used the Mann-Whitney nonparametric test to perform quantitative analysis of collagen. We used the Kruskal-wallis nonparametric to analyze variance between different times of the procedure $\left(3^{\text {rd }}, 7^{\text {th }}\right.$, and $14^{\text {th }}$ day). We used Fisher's exact test to detect differences in inflammation stages between groups and timings. We used IBM SPSS Statistics v.20 system to analyze data. Statistical significance was defined by p-values of 0.05 or less.

Specimens also underwent immunohistochemistry evaluation to determine reactivity to factor VIII, CD34, and $\alpha$ smooth muscle actin (A-SMA). However, only the A-SMA analysis was possible since factor VIII and CD34 presented decreased specificity for staining on the evaluated tissue. Afterwards, we sent all the results for statistical analysis, which was conducted utilizing parametric and nonparametric methods.

\section{Results}

\section{HE Stain}

We made comparisons between the groups (control and experimental) regarding stages of inflammatory process (acute, subacute, or chronic) at different times of tissue removal $\left(3^{\text {rd }}, 7^{\text {th }}\right.$, and $14^{\text {th }}$ day). Subsequently, we compared each time separately ( $3^{\text {rd }}$ day versus $7^{\text {th }}$ day; $3^{\text {rd }}$ day versus

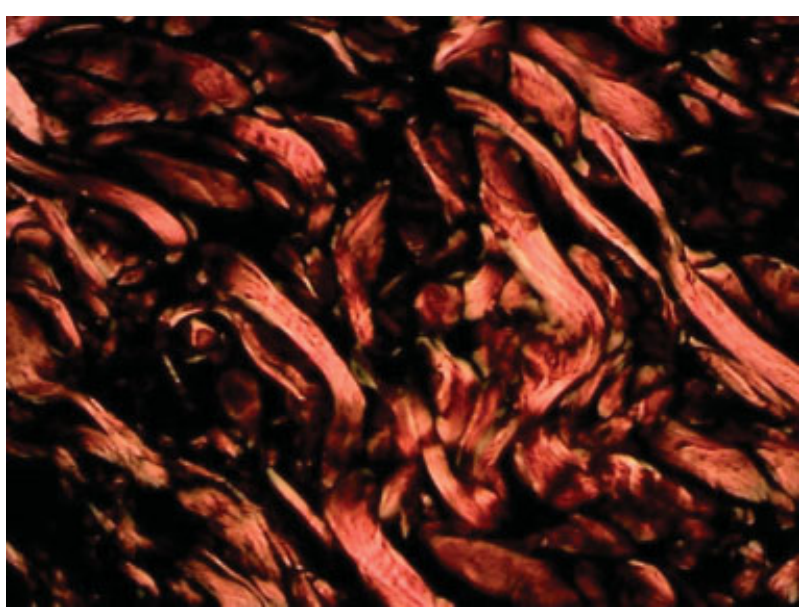

Fig. 1 Picrosirius stain for experimental group (D7) demonstrating mature collagen and immature collagen. $14^{\text {th }}$ day; $7^{\text {th }}$ day versus $14^{\text {th }}$ day). The null hypothesis of distribution equality among inflammation stages in both groups was tested and contrasted to the alternate hypothesis of diverse distribution.

No differences were found in the inflammatory process concerning the two analyses on the third day $(p=1)$, seventh day $(p=0.474)$, and fourteenth day $(p=0.303)$.

\section{Picrosirius Red Stain}

We performed a quantitative comparison of collagen type I between different times of tissue removal for the control group and experimental group separately. We found no differences among the different times of analysis in the control group. Furthermore, we detected no differences within the experimental group: third day $(p=0.436)$, seventh day ( $p=0.853)$, fourteenth day $(p=0.436)$ ( - Fig. 1) As for collagen type III, we ran the same analysis and the control group had no significant differences; whereas within the experimental group, statistical differences were apparent between subgroups on day 3 and day $14(p=0.005)$ (-Fig. 2 ).

\section{A-SMA}

Immunohistochemical analysis revealed brown staining of ASMA. This area highlights the presence of myofibroblasts and allows vessel count for angiogenesis evaluation. We executed an analysis of the presence of myofibroblasts in a delimited area, and then contrasted control and experimental group

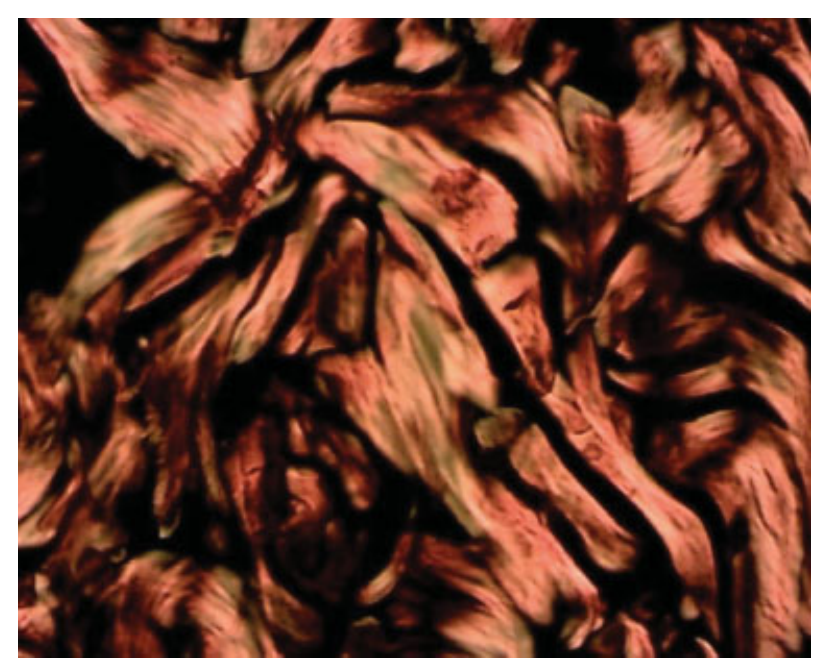

Fig. 2 Picrosirius stain for control group (D7) demonstrating mature collagen and immature collagen. 
Table 2 Immunohistochemistry results obtained per day and per group of myofibroblasts

\begin{tabular}{|l|l|l|l|l|l|l|l|l|}
\hline \multirow{2}{*}{ Evaluation time } & \multirow{2}{*}{ Group } & \multicolumn{4}{l|}{ Brown colored area myofibroblasts } & \multicolumn{2}{l|}{$\boldsymbol{p}$ value } \\
\cline { 3 - 9 } & & $\mathbf{n}$ & Mean & Median & Min & Max & SD & \\
\hline Day 3 & Control & 10 & 5118 & 4867 & 1867 & 8542 & 2478 & \\
\hline & Experimental & 10 & 5649 & 5125 & 3851 & 9890 & 1897 & 0.684 \\
\hline Day 7 & Control & 10 & 6751 & 6462 & 3977 & 8784 & 1692 & \\
\hline & Experimental & 10 & 5551 & 5674 & 3503 & 7696 & 1210 & 0.143 \\
\hline Day 14 & Control & 10 & 6283 & 6546 & 2403 & 11421 & 2335 & \\
\hline & Experimental & 10 & 6557 & 6828 & 3927 & 8835 & 1923 & 0.631 \\
\hline
\end{tabular}

*Mann-Whitney non-parametric test; $p<0.05$. Abbreviation: SD, standard deviation.

according to the time of tissue removal. Results were not statistically significant by the third day $(p=0.684)$, seventh day ( $p=0.143)$, and fourteenth day $(p=0.631)$ ( - Table 2$)$.

Subsequently, we evaluated the null hypothesis of equal means among all times and contrasted it with the alternate hypothesis of the presence of divergent results on at least one of the timings. The null hypothesis could not be rejected by statistical tests for both control group $(p=0.336)$ and experimental group ( $p=0.4$ ) ( Table 2 ).

When contrasting immunohistochemical analysis of control and experimental group for A-SMA presence, we found no statistical differences.

For angiogenesis evaluation, we compared times of tissue removal between groups. We found no statistically significant results on the third day $(p=0.280)$, seventh day $(p=0.971)$, and fourteenth day $(p=0.218)$ (-Table 3 ).

Afterwards, the null hypothesis of equal means was tested versus the alternative hypothesis that at least one of the times presented different results. Statistical testing could not rule out the null hypothesis for the control group $(p=0.389)$ and the experimental group $(p=0.091)$. When we evaluated angiogenesis among groups, we did not find statistical difference.

\section{Discussion}

BS is commonly used in adenotonsillectomies with homeostatic purposes. BS enhances the intrinsic pathway of blood coagulation by activating factor XII. ${ }^{12,13}$ Therefore, this study was developed to elucidate its role in wound healing. BS could be of potential benefit considering that several hemostatic techniques are being explored to reveal efficient methods of trans- and postoperative bleeding control. Some trials have described BS as being a heavy metal element that is prohomeostatic and stimulates clot formation. ${ }^{12,13}$ Nonetheless, there is a lack of studies analyzing its effects on wound healing.

Another study developed in the city of Curitiba, Brazil, evaluated the effects of the application of BS over wounds performed on the mucosa on the back of rats. This investigation revealed that BS inhibits fibroplasia and angiogenesis, therefore, delaying the wound healing process. ${ }^{13}$ Diversely, our study showed no effects of BS on wound healing. Given that both studies performed identical application of $0.5 \mathrm{mg}$ of BS over the wounds, we hypothesize that the divergence was due to the wound being performed in the mucosa that study, whereas, in our study, it was done on the skin. Mucous membrane consists of the combination of an epithelium and a lamina propria of connective tissue, which line some body cavities. The mucosa's lamina propria consists of a nonkeratinized epithelial tissue, whereas the skin presents keratinized stratified squamous epithelium. ${ }^{14}$ This could explain differences in wound healing effects on tissues. We hypothesize that the lack of keratinized tissue exposed tissues to a higher concentration of BS, reaching, thus, toxic levels and impairing wound healing. The keratinized surface of skin,

Table 3 Immunohistochemistry results obtained per day and per number of vessels

\begin{tabular}{|c|c|c|c|c|c|c|c|c|}
\hline \multirow[t]{2}{*}{ Evaluation time } & \multirow[t]{2}{*}{ Group } & \multicolumn{6}{|c|}{ Number of vessels } & \multirow[t]{2}{*}{$p$ value* } \\
\hline & & $\mathbf{n}$ & Mean & Median & Min & Max & SD & \\
\hline \multirow[t]{2}{*}{ Day 3} & Control & 10 & 2.5 & 2 & 0 & 5 & 2.0 & \\
\hline & Experimental & 10 & 1.5 & 1.5 & 0 & 4 & 1.5 & 0.280 \\
\hline \multirow[t]{2}{*}{ Day 7} & Control & 10 & 3.4 & 3 & 1 & 8 & 2.5 & \\
\hline & Experimental & 10 & 3.3 & 3.5 & 1 & 6 & 1.9 & 0.971 \\
\hline \multirow[t]{2}{*}{ Day 14} & Control & 10 & 2.1 & 2 & 0 & 7 & 1.9 & \\
\hline & Experimental & 10 & 2.4 & 2 & 1 & 4 & 0.8 & 0.218 \\
\hline
\end{tabular}

*Mann-Whitney nonparametric test; $p<0.05$. Abbreviation: SD, standard deviation. 
however, may have acted as a barrier, preventing BS induced toxicity and, thus, not influencing cicatrization.

Notwithstanding, another study presented similar results to the ones described in this project. The research team performed a standard wound with a circular scalpel on the back of 55 Wistar rats to evaluate the effects of BS on tissue regeneration. They traced an imaginary line to divide the wound into two equal parts. The right part was treated with BS and the other one with physiological saline $0.9 \%$. We found no differences between the utilization of these two compounds over different time analyses. Therefore, BS did not enhance tissue regeneration. ${ }^{15}$ Bias cannot be ruled out in this study, though, since the same wound was used for the analysis of both substances. Nonetheless, the results are similar to ours.

Another study also corroborates our findings. Hepatectomies were performed using a metallic scalpel on 30 rats. Animals were divided into two groups. One group utilized an electrosurgical device for hemostatic purposes while the other group used BS. Subsequently, we performed histological analyses to detect: necrosis, fibrosis, thrombosis of the microcirculation, granulomatous reaction, inflammation stage, and adhesions. We found no differences among groups regarding granulomatous reaction, necrosis, fibrosis, inflammation stage, and adhesions. ${ }^{16}$ This strengthens the notion that BS does not alter the inflammation process and wound healing.

This project reveals that the use of BS is tolerable and safe and that it does not remarkably influence the wound healing process. Both wounds on D14 were cicatrized and presented similar ectoscopy. The lack of substantial effects on wound healing was determined by HE stain, picrosirius stain, and immunohistochemistry. ${ }^{17}$

The findings of this study indicate that BS is neither harmful nor helpful regarding wound healing.

\section{Conclusion}

Based on the data presented here, study limitations that could be addressed in future research is a bigger population of rats and BS absorption characteristics. Future trials comparing other substances with the control group is also warranted to increase the validity of our results.

In conclusion, BS does not promote significant changes in the inflammatory process, collagen production, and angiogenesis. Thus, BS is neither harmful nor helpful regarding wound healing on skin wounds of rats.

\section{References}

1 Brasileiro HMS, Lee IWC, Rapoport A. Uso do subgalato de bismuto como agente hemostático em tonsiléctomia palatina: Estudo de 201 casos. ACTA ORL 2006;24(3):181-185

2 Kim SH, Grein RL, Tramontina VA. Aplicação do subgalato de bismuto em cirurgia periodontal. JBC J Bras Odontol Clin. 1997; $1(1): 31-34$

3 Pillar RS, Brito EO. Aplicação do subnitrato de bismuto e do subgalato nas amigdaléctomias. Arq Otorrinolaringol. 2003;7(1):28-31

4 Lazarus GS, Cooper DM, Knighton DR, et al. Definitions and guidelines for assessment of wounds and evaluation of healing. Arch Dermatol 1994;130(4):489-493

5 Robson MC. Wound infection. A failure of wound healing caused by an imbalance of bacteria. Surg Clin North Am 1997;77(3):637-650

6 Mandelbaum SH, Di Santis EP, Mandelbaum MHS. Cicatrização: conceitos atuais e recursos auxiliares/ Parte I. An Bras Dermatol 2003;78(4):393-410

7 Baum CL, Arpey CJ. Normal cutaneous wound healing: clinical correlation with cellular and molecular events. Dermatol Surg 2005;31(6):674-686

8 Hanson D, Langemo D, Thompson P, Anderson J, Hunter S. Understanding wound fluid and the phases of healing. Adv Skin Wound Care 2005;18(7):360-362

9 Dieter MF. Ação do medicamento canova na cicatrização do dorso de camundongo após incisão e sutura: avaliação macro e microscópica [dissertation]. Curitiba: University of Parana; 2005

10 Feridas IG. Novas Abordagens, Manejo Clínico e Atlas em Cores. Rio de Janeiro, Brazil: Editora LAB; 2005:178-179

11 Vizzotto Junior AO, Noronha L, Scheffel DLH, Campos ACL. Influência da cisplatina administrada no pré e pós-operatório sobre a cicatrização de anastomoses colônicas em ratos. J Bras Patol Med Lab 2003;39(2):143-149

12 Tramontina VA. Efeito do subgalato de bismuto no processo de reparação de feridas em dorso de rato. Estudo experimental histológico, histométrico e fotográfico. [dissertation]. Campinas: Universidade Estadual de Campinas. Faculdade de Odontologia de Piracicaba. 1997

13 Seidel KC, Sampaio CPP. Avaliação dos efeitos do subgalato de bismuto na cicatrização: avaliação do processo inflamatório e da proliferação dos miofibroblastos. Poster session presented at: Congresso Brasileiro de Otorrinolaringologia, Nov 20-23, 2013; São Paulo, Brazil

14 Manterola ER, Smerilli AL. Uso del subgalato de bismuto como técnica hemostática en la exodoncia para pacientes dializados. Rev Fac Odontol (UBA) 2007;22:52-5325-27

15 Tramontina VA. Efeito do subgalato de bismuto no processo de reparação de feridas em dorso de rato. Estudo experimental, histológico, histométrico e fotográgico [dissertation]. Campinas: Universidade Estadual de Campinas. Faculdade de Odontologia de Piracicaba, Piracicaba, Brazil, 1997

16 Arroyo PC Jr, et al. Uso do subgalato de bismuto para hemostasia local em hepatectomias parciais em ratos. Rev Col Bras Cir 2004; 31(3):165 [online]

17 Feridas IG. Novas Abordagens, Manejo Clínico e Atlas em Cores. Rio de Janeiro, Brazil: Editora LAB; 2005:178-179 